\title{
Effect of source and methods of zinc application on corn productivity, nitrogen and zinc concentrations and uptake by high quality protein corn (Zea mays)
}

\section{Yashbir Singh Shivay* \& Rajendra Prasad}

Division of Agronomy, Indian Agricultural Research Institute, New Delhi 110 012, India

\begin{abstract}
Results of a field study conducted at the Indian Agricultural Research Institute, New Delhi, India showed that the combined application of soil + foliar (in two sprays at tasseling and initiation of flowering) produced significantly more grain and stover yields than either soil or foliar applications alone. Application of $\mathrm{Zn}$-coated urea was better than soil application of $\mathrm{Zn}$ sulphate with regard to grain and stover yields. The combined application also recorded the highest $\mathrm{Zn}$ concentration in corn grain as well as in stover, with the treatments falling in the following order: combined $>$ foliar $>$ soil through $\mathrm{Zn}$-coated urea $>$ soil. This is an important finding for the agronomic biofortification of $\mathrm{Zn}$ in corn.
\end{abstract}

Keywords: Crude protein; foliar application of zinc, zinc biofortification, zinc-coated urea, zinc sulphate.

\section{Introduction}

Corn (Zea mays L.) is a major cereal crop widely grown and consumed in developed as well as in developing countries. In India it is cultivated on an area of 8.55 million hectares with a production of 22.50 million $\mathrm{Mg}$ and an average productivity of $2.54 \mathrm{Mg} \mathrm{ha}^{-1}$ (Fertilizer Statistics 2011-12). Widespread deficiencies of zinc ( $\mathrm{Zn}$ ) have been reported right through East Asia, to the tune of 50-70 \% in India and Pakistan. Cereal grains are known to be inherently low in Zn, particularly in regions where soils are low in plant-available Zn (Shivay \& Prasad 2012). Nearly $50 \%$ of cereal-growing areas in the world have soils with low plant-available $\mathrm{Zn}$ (Graham \& Welch 1996, Cakmak 2002), resulting in Zn concentrations in cereal grains of as little as 5-12 mg kg${ }^{-1}$ against a requirement of 40-60 $\mathrm{mg} \mathrm{kg}^{-1}$ (www.harvestplus.org, Pfeiffer $\&$ McClafferty 2007). Since the introduction of the Green Revolution in Asia, cultivation of high yielding genotypes, improved agricultural mechanization and production of macronutrient fertilizers with low impurities of trace elements has resulted in higher crop production per unit area and greater depletion of plant-available micronutrients (Cakmak 2008, Khoshgoftarmanesh et al. 2009). Most micronutrient deficiency problems are exacerbated by the cultivation of high-yielding crop cultivars that quickly deplete the limited soil nutrients (Cakmak et al. 1996, Martens \& Lindsay 1990). This presents a further challenge for addressing Zn deficiency in cereal-based cropping systems.

$\mathrm{Zn}$ is required for structural and functional integrity of about 2,800 proteins, contributes to protein biosynthesis and is a key defence factor in detoxification of highly toxic oxygen-free radicals (Cakmak 2000, Broadley et al. 2007). Therefore Zn deficiency in cultivated soils, as documented at global level (Alloway 2004), poses a serious threat to crop production and human nutrition. Cereal-based diets are the major source of nutrients for the majority of the world's population, but over the past two to three decades, concentrations of essential minerals such as $\mathrm{Zn}$ have been found to be on a downward trend, far below the required $25-50 \mathrm{mg} \mathrm{Zn}$ $\mathrm{kg}^{-1}$ (FAO 1996). Although meat is known to have a high $\mathrm{Zn}$ concentration, it is not readily available to many resource-constrained households who often constitute more than $60 \%$ of the population in developing countries (Paul et al. 1998, Cakmak et al. 1999). Zn deficiency in humans was rated by WHO (2002) as fifth of the ten leading causes of illness and disease, especially in women and children in low-income countries. Health problems associated with

* Author for correspondence: email : ysshivay@hotmail.com 
Zn deficiency include pregnancy complications, low birth weight, impairments in brain development and function, and growth faltering in infants and children (Gibson 1994).

Approaches for improving the nutritional wellbeing of humans such as food diversification, supplementation with capsules or syrups, molecular biology and industrial food fortification still require much investment and social acceptance (Ruel \& Bouis 1998, White \& Broadley 2005). Conventionally, the use of inorganic $\mathrm{Zn}$ fertilizers and synthetic chelates provide avenues to alleviate $\mathrm{Zn}$-deficiency-related problems both in human nutrition and crop production. It is better to increase the $\mathrm{Zn}$ content in cereals, the staple food in many developing countries, through $\mathrm{Zn}$ fertilization. Biofortification of cereals can be achieved either by developing crop cultivars with high concentrations of $\mathrm{Zn}$ in the grain, or by adequate $\mathrm{Zn}$ fertilization of crops grown on Zn-deficient soils. Agronomic fortification of corn by increasing $\mathrm{Zn}$ concentration and its bioavailability has great potential to alleviate its deficiency. The present study was conducted to evaluate the effect of source and methods of $\mathrm{Zn}$ application on corn productivity, nitrogen and $\mathrm{Zn}$ concentrations and uptake by high-quality protein corn.

\section{Materials \& Methods}

The field experiment was conducted at the Research Farm of the Indian Agricultural Research Institute, New Delhi, India $\left(28^{\circ} 38^{\prime} \mathrm{N}, 77^{\circ} 10^{\prime} \mathrm{E}\right.$, altitude $\left.228.6 \mathrm{~m}\right)$ during the rainy season (July to mid-November) of 2008 on a sandy-loam soil ('ustrochrept'). The soil had $165 \mathrm{~kg} \mathrm{ha}^{-1}$ alkaline permanganate oxidizable N (Subbiah \& Asija 1956), $18.2 \mathrm{~kg} \mathrm{ha}^{-1}$ available $\mathrm{P}$ (Olsen et al. 1954), $315 \mathrm{~kg} \mathrm{ha}^{-1} 1 \mathrm{~N}$ ammonium acetate exchangeable $\mathrm{K}$ (Hanway \& Heidel 1952) and $0.378 \%$ organic $\mathrm{C}$ (Walkley \& Black 1934). The $\mathrm{pH}$ of the soil was 8.3 (1:2.5 soil: water ratio) (Prasad et al. 2006) and the DTPA-extractable Zn (Lindsay \& Norvell 1978) in the soil was $0.36 \mathrm{mg} \mathrm{kg}^{-1}$ soil.

There were five treatments: control (no $\mathrm{Zn}$ ), soil application of $5 \mathrm{~kg} \mathrm{Zn} \mathrm{ha}^{-1}$ as $\mathrm{ZnSO}_{4} \cdot 7 \mathrm{H}_{2} \mathrm{O}$, foliar application of $1 \mathrm{~kg} \mathrm{Zn} \mathrm{ha}^{-1}$ as $\mathrm{ZnSO}_{4} \cdot 7 \mathrm{H}_{2} \mathrm{O}$ (in two sprays at tasseling and initiation of flowering), $5 \mathrm{~kg} \mathrm{Zn} \mathrm{ha}^{-1}$ as $\mathrm{ZnSO}_{4} .7 \mathrm{H}_{2} \mathrm{O}$ (soil application) $+1 \mathrm{~kg} \mathrm{Zn} \mathrm{ha}^{-1}$ as $\mathrm{ZnSO}_{4} .7 \mathrm{H}_{2} \mathrm{O}$ as foliar application (in two sprays at tasseling and initiation of flowering) and soil application of $\mathrm{Zn}$-coated urea (1.0\% $\mathrm{Zn}$ through $\mathrm{ZnO}$ amounting to an application of 2.83 $\mathrm{Zn} \mathrm{ha}^{-1}$ ) (soil). These treatments were tested in a randomized block design with 3 replications.

The experimental field was disk-ploughed twice, cultivated three times with a cultivator and levelled. Corn ('High Quality Protein Maize 1') was planted at a spacing of $45 \mathrm{~cm}$ x $20 \mathrm{~cm}$ in the first week of August. The plot size was $5.0 \mathrm{~m} \mathrm{x} 2.7 \mathrm{~m}$ for each treatment. At final ploughing $26 \mathrm{~kg} \mathrm{P} \mathrm{ha}^{-1}$ as single superphosphate was broadcast. Nitrogen at $130 \mathrm{~kg} \mathrm{~N}^{-1}$ as PU or Zn-coated urea was band-applied in two equal splits, half at planting and the other half at tasseling stage. Soil application of $\mathrm{Zn}$ sulphate was made by banding in rows just before corn planting. Foliar application of $\mathrm{Zn}$ sulphate was made twice; first just before tasseling development and the second a week after flowering. For foliar application, 500 litres of $0.5 \%$ solution of $\mathrm{Zn}$ sulphate was used; thus two sprays supplied $5 \mathrm{~kg} \mathrm{Zn}$ sulphate $\mathrm{ha}^{-1}$. Corn was grown as per recommended practices.

To record growth, yield attributes and yields of corn, five plants were randomly selected in each plot, measuring various attributes before harvesting (cob length, cob girth, grain weight per cob and 1,000-grain weight etc.). At harvest, the grain yield and stover yield were recorded for each plot and expressed in $\mathrm{Mg} \mathrm{ha}^{-1}$.

For chemical analysis, at harvest samples of grain and stover were drawn from each plot of the experiment. $\mathrm{Zn}$ in grain and straw samples was analysed on a di-acid $\left(\mathrm{HClO}_{4}+\right.$ $\mathrm{HNO}_{3}$ in 3:10 ratio) digest on an Atomic Absorption Spectrophotometer (Prasad et al. 2006). Total $\mathrm{N}$ was determined by Kjeldahl method (Prasad et al. 2006). Therefore, the uptake of the nitrogen and $\mathrm{Zn}$ was calculated by multiplying $\mathrm{N}$ and $\mathrm{Zn}$ concentrations with respective plot 
yield of grain and stover of corn. Crude protein content in corn was determined by multiplying the $\mathrm{N}$ concentration by 6.25 .

$\mathrm{Zn}$ use efficiencies (Zn harvest index - ZnHI, agronomic efficiency - AE, recovery efficiency - RE, and Zn mobilization efficiency index - ZnMEI) of the applied Zn were computed using the following expressions as suggested by Shivay et al. (2010):

$$
\begin{aligned}
& \mathrm{AE}=\left(\mathrm{Y}_{\mathrm{t}}-\mathrm{Y}_{\mathrm{o}}\right) / \mathrm{Zn}_{\mathrm{a}} \\
& \mathrm{RE}=\left[\left(\mathrm{U}_{\mathrm{t}}-\mathrm{U}_{\mathrm{o}}\right) / \mathrm{Zn}_{\mathrm{a}}\right] \times 100 \\
& \mathrm{ZnHI}=\left(\mathrm{Zn}_{\mathrm{s}} / \mathrm{Zn}_{\mathrm{t}}\right) \times 100 \\
& \mathrm{ZnMEI}=[\mathrm{Zn} \text { concentration in grain } \div \mathrm{Zn} \text { concentration in straw }]
\end{aligned}
$$

where, $\mathrm{Y}_{\mathrm{t}}=$ yield in the treatment $\left(\mathrm{kg} \mathrm{ha}^{-1}\right) ; \mathrm{Zn}_{\mathrm{a}}=$ amount of $\mathrm{Zn}$ added $\left(\mathrm{kg} \mathrm{ha}^{-1}\right) ; \mathrm{Y}_{\mathrm{o}}=$ yield of the control treatment $\left(\mathrm{kg} \mathrm{ha}^{-1}\right) ; \mathrm{U}_{\mathrm{t}}=$ uptake of $\mathrm{Zn}$ in test treatment $\left(\mathrm{kg} \mathrm{ha}^{-1}\right) ; \mathrm{U}_{\mathrm{o}}=$ uptake of $\mathrm{Zn}$ in control treatment $\left(\mathrm{kg} \mathrm{ha}^{-1}\right) ; \mathrm{Zn}_{\mathrm{s}}=\mathrm{Zn}$ uptake by grain at harvest, and $\mathrm{Zn}_{\mathrm{t}}=\mathrm{Zn}$ uptake by whole crop (grain + stover) at harvest.

All the data recorded during the experiment were subjected to statistical analysis using the $F$-test as per the procedure given by Gomez \& Gomez (1984). Least significant difference (LSD) values at $P=0.05$ were used to determine the significance of differences between treatment means.

\section{Results}

A significant improvement in yield attributes of corn was recorded with $\mathrm{Zn}$ fertilization (Table 1). The longest cob length was recorded with the combined soil+foliar application of $\mathrm{Zn}$, significantly greater than the control. Mean cob girths were not significantly different among treatments, but slightly higher values were recorded with application of $\mathrm{Zn}$ compared to control. Significant improvements in the grain weight $\mathrm{cob}^{-1}$ over the control were recorded for all $\mathrm{Zn}$ treatments except the foliar treatment, with the highest mean value recorded for the combined soil + foliar application, not statistically different from the soil and the Zn-coated urea treatments. Zn fertilization treatments did not influence the 1,000-grain weight significantly, but again the highest mean value was recorded for the combined treatment.

\begin{tabular}{lcccccc}
\hline $\begin{array}{l}\text { Treatment } \\
\left.\text { (all values are quantities of } \mathbf{Z n ~ h a}^{-\mathbf{1}}\right)\end{array}$ & $\begin{array}{c}\text { Cob } \\
\text { length } \\
(\mathbf{c m})\end{array}$ & $\begin{array}{c}\text { Cob } \\
\text { girth } \\
(\mathbf{c m})\end{array}$ & $\begin{array}{c}\text { Grain } \\
\text { weight } \\
\left(\mathbf{g ~ c o b}^{-1}\right)\end{array}$ & $\begin{array}{c}\mathbf{1 , 0 0 0 -} \\
\text { grain wt } \\
(\mathbf{g})\end{array}$ & $\begin{array}{c}\text { Grain } \\
\text { yield } \\
\left(\mathbf{M g ~ h a}^{-1}\right)\end{array}$ & $\begin{array}{c}\text { Stover } \\
\text { yield } \\
\left(\mathbf{M g ~ h a}^{-\mathbf{1}}\right)\end{array}$ \\
\hline control (no added Zn) & 13.0 & 3.59 & 70.6 & 190.0 & 4.00 & 6.10 \\
5 kg to soil & 14.0 & 3.70 & 74.9 & 199.3 & 4.70 & 6.68 \\
1 kg foliar & 13.5 & 3.63 & 72.8 & 193.3 & 4.42 & 6.50 \\
5 kg to soil + 1 kg foliar & 15.2 & 3.73 & 76.5 & 201.5 & 5.10 & 7.03 \\
2.83 kg through Zn-coated urea (to soil) & 14.4 & 3.64 & 75.2 & 200.5 & 4.80 & 6.90 \\
sem & 0.6 & 0.06 & 1.3 & 3.9 & 0.12 & 0.19 \\
LSD (for p=0.05) & 2.1 & $\mathrm{NS}$ & 4.1 & $\mathrm{NS}$ & 0.38 & 0.62 \\
\hline
\end{tabular}

Table 1: Effect of source and method of $\mathrm{Zn}$ application on yield attributes and yield of corn

As might be expected from the data on yield attributes, grain and stover yield of corn was the highest with the combined soil + foliar application of $\mathrm{Zn}$ (Table 1), significantly higher than all the other treatments $(5-15 \%)$ and the control (27\%). The mean stover yields were significantly different among treatments, all due to the control being below those of all the $\mathrm{Zn}$ treatments; 
again the combined treatment recorded the highest mean value. In both grain yields and stover, $\mathrm{Zn}$ applied to the soil as $\mathrm{Zn}$-coated urea had higher mean values than when applied as $\mathrm{Zn}$ sulphate, but the differences were not significant.

Nitrogen concentration and uptake in corn grain and stover and total uptake in corn grain was the highest with the combined soil + foliar treatment (Table 2). The mean values for the single soil applications of $\mathrm{Zn}$ sulphate or zinc-coated urea were very similar, and higher than those for the foliar application of $\mathrm{Zn}$.

\begin{tabular}{|c|c|c|c|c|c|c|}
\hline \multirow[b]{2}{*}{$\begin{array}{l}\text { Treatment } \\
\text { (all values are quantities of } \mathrm{Zn} \mathrm{ha}^{-1} \text { ) }\end{array}$} & \multicolumn{2}{|c|}{$\mathrm{N}$ concentration } & \multicolumn{3}{|c|}{ N uptake } & \multirow{2}{*}{$\begin{array}{c}\text { Crude } \\
\text { protein } \\
\text { content } \\
(\%)\end{array}$} \\
\hline & $\begin{array}{c}\text { Corn } \\
\text { grain } \\
(\%)\end{array}$ & $\begin{array}{c}\text { Corn } \\
\text { stover } \\
(\%) \\
\end{array}$ & $\begin{array}{c}\text { Corn } \\
\text { grain } \\
\left(\mathrm{kg} \mathrm{ha}^{-1}\right) \\
\end{array}$ & $\begin{array}{c}\begin{array}{c}\text { Corn } \\
\text { stover } \\
\left(\mathrm{kg} \mathrm{ha}^{-1}\right)\end{array} \\
\end{array}$ & $\begin{array}{c}\text { Total } \\
\left(\mathrm{kg} \mathrm{ha}^{-1}\right)\end{array}$ & \\
\hline control (no added Zn) & 1.44 & 0.58 & 57.6 & 35.4 & 93.0 & 9.0 \\
\hline $5 \mathrm{~kg}$ to soil & 1.60 & 0.64 & 75.2 & 42.8 & 118.0 & 10.0 \\
\hline $1 \mathrm{~kg}$ foliar & 1.54 & 0.60 & 68.1 & 39.0 & 107.1 & 9.6 \\
\hline $5 \mathrm{~kg}$ to soil $+1 \mathrm{~kg}$ foliar & 1.64 & 0.66 & 83.6 & 46.4 & 130.0 & 10.3 \\
\hline $2.83 \mathrm{~kg}$ through $\mathrm{Zn}$-coated urea (to soil) & 1.57 & 0.65 & 75.6 & 44.9 & 120.3 & 9.8 \\
\hline sem & 0.03 & 0.01 & 1.7 & 1.3 & 2.0 & 0.3 \\
\hline LSD (for $\mathrm{p}=0.05$ ) & 0.09 & 0.03 & 5.4 & 4.1 & 6.4 & 1.0 \\
\hline
\end{tabular}

Table 2: Effect of source and method of $\mathrm{Zn}$ application on $\mathrm{N}$ concentration in corn grain and stover and their uptake and also crude protein content in corn grain

Zn fertilization increased the crude protein content (Table 2), but this was only significant for treatments involving soil applications as $\mathrm{Zn}$ sulphate. The combined soil + foliar application recorded the highest mean value. Although higher, there were no significant differences between soils vs. foliar application, nor between application as $\mathrm{Zn}$ coated urea vs. Zn sulphate.

The mean values for $\mathrm{Zn}$ concentrations and uptake were all highest for the combined soil + foliar treatment, and always significantly superior to all other treatments (Table 3). Higher mean values were always seen for foliar than soil application, often significantly so. Soil application as Zn-coated urea was nearly always statistically higher than application as $\mathrm{Zn}$ sulphate. All $\mathrm{Zn}$ treatments for agronomic biofortification of $\mathrm{Zn}$ in corn grain as well as in stover were in the following order: $5 \mathrm{~kg}$ soil $+1 \mathrm{~kg}$ foliar $>1 \mathrm{~kg}$ foliar $>2.83 \mathrm{~kg}$ as $\mathrm{Zn}$-coated urea to soil $>5 \mathrm{~kg}$ soil.

\begin{tabular}{|c|c|c|c|c|c|}
\hline \multirow[b]{2}{*}{$\begin{array}{l}\text { Treatment } \\
\text { (all values are quantities of } \mathrm{Zn} \mathrm{ha}^{-1} \text { ) }\end{array}$} & \multicolumn{2}{|c|}{ Zn concentration } & \multicolumn{3}{|c|}{ Zn uptake } \\
\hline & $\begin{array}{l}\text { Corn } \\
\text { grain } \\
\text { (mg kg } \\
\text { grain) }\end{array}$ & $\begin{array}{c}\text { Corn } \\
\text { stover } \\
\text { (mg kg } \\
\text { DM) }\end{array}$ & $\begin{array}{c}\text { Corn } \\
\text { grain } \\
\left(\mathrm{g} \mathrm{ha}^{-1}\right)\end{array}$ & $\begin{array}{c}\text { Corn } \\
\text { stover } \\
\left(\mathrm{g} \mathrm{ha}^{-1}\right)\end{array}$ & $\begin{array}{l}\text { Total } \\
\left(\text { g ha }^{-1}\right)\end{array}$ \\
\hline control (no added $\mathrm{Zn}$ ) & 40.2 & 45.0 & 160.8 & 274.5 & 435.3 \\
\hline $5 \mathrm{~kg}$ to soil & 44.2 & 49.2 & 207.7 & 328.5 & 536.4 \\
\hline $1 \mathrm{~kg}$ foliar & 46.0 & 59.2 & 203.2 & 384.8 & 588.0 \\
\hline $5 \mathrm{~kg}$ to soil $+1 \mathrm{~kg}$ foliar & 49.2 & 64.5 & 250.9 & 453.4 & 704.3 \\
\hline $2.83 \mathrm{~kg}$ through $\mathrm{Zn}$-coated urea (to soil) & 45.8 & 58.2 & 219.8 & 401.6 & 621.4 \\
\hline sem & 0.6 & 0.8 & 3.4 & 3.4 & 3.8 \\
\hline $\operatorname{LSD}($ for $\mathrm{p}=0.05)$ & 2.0 & 2.7 & 11.1 & 11.1 & 12.5 \\
\hline
\end{tabular}

Table 3: Effect of source and method of $\mathrm{Zn}$ application on $\mathrm{Zn}$ concentration in grain and stover of corn and its $\mathrm{Zn}$ uptake by corn 
$\mathrm{Zn}$ use efficiencies were influenced significantly by $\mathrm{Zn}$ treatment (Table 4). The highest harvest index was recorded for the single soil application $\mathrm{Zn}$ sulphate, significantly higher than all other $\mathrm{Zn}$ treatments, but not the control. Similar results were also observed with the mobilization efficiency index. All treatments were significantly different from one another with respect to agronomic efficiency, and as expected, this was much the highest with the foliar treatment and lowest with the soil treatment (as $\mathrm{Zn}$ sulphate). The recovery index varied from substantially due to different $\mathrm{Zn}$ treatments. All $\mathrm{Zn}$ treatments for agronomic efficiency and recovery efficiency were in the following order: $1 \mathrm{~kg} \mathrm{Zn} \mathrm{ha}^{-1}$ (foliar) $>2.83 \mathrm{~kg} \mathrm{Zn} \mathrm{ha}^{-1}$ through Zn-coated urea (soil) $>5 \mathrm{~kg} \mathrm{Zn} \mathrm{ha}^{-1}$ (soil) $+1 \mathrm{~kg} \mathrm{Zn} \mathrm{ha}^{-1}$ (foliar) $>5 \mathrm{~kg} \mathrm{Zn} \mathrm{ha}^{-1}$ (soil).

\begin{tabular}{lccrr}
\hline $\begin{array}{l}\text { Treatment } \\
\text { (all values are quantities of } \mathbf{Z n} \mathbf{~ h a}^{-\mathbf{1}} \text { ) }\end{array}$ & $\begin{array}{c}\text { harvest } \\
\text { index } \\
(\boldsymbol{\%})\end{array}$ & $\begin{array}{c}\text { mobilization } \\
\text { efficiency } \\
\text { index }\end{array}$ & $\begin{array}{c}\text { agronomic } \\
\text { efficiency }\end{array}$ & $\begin{array}{c}\text { recovery } \\
\text { efficiency } \\
(\boldsymbol{\%})\end{array}$ \\
\hline control (no added Zn) & 36.9 & 0.89 & - & - \\
5 kg to soil & 38.7 & 0.90 & 140 & 2.02 \\
1 kg foliar & 34.6 & 0.78 & 420 & 15.27 \\
5 kg to soil + 1 kg foliar & 35.6 & 0.76 & 183 & 4.48 \\
2.83 kg through Zn-coated urea (to soil) & 35.4 & 0.79 & 283 & 6.58 \\
sem & 0.6 & 0.01 & 3 & 0.02 \\
LSD (for $\mathrm{p}=0.05$ ) & 2.1 & 0.03 & 9 & 0.08 \\
\hline
\end{tabular}

Table 4: Effect of source and method of Zn application on Zn use efficiencies in corn

\section{Discussion}

In the present study most yield attributes, grain and stover yield, $\mathrm{N}$ and $\mathrm{Zn}$ concentrations and uptake by corn were the highest with the combined soil + foliar application of $\mathrm{Zn}$ sulphate, and partly this could be due to the higher amount of $\mathrm{Zn}$ sulphate $\left(6 \mathrm{~kg} \mathrm{Zn} \mathrm{ha}^{-1}\right)$ involved. In general, soil application of $\mathrm{Zn}$ was superior to foliar application in respect of yield attributes, grain and stover yield, and $\mathrm{N}$ concentration and uptake by corn, which again may partly be due to the application of a larger amount $\left(5 \mathrm{~kg} \mathrm{Zn} \mathrm{ha}^{-1}\right)$ through soil as opposed to foliar application $\left(1 \mathrm{~kg} \mathrm{Zn} \mathrm{ha}{ }^{-1}\right)$, and partly due the fact that soil application was made at planting, while foliar application was made much later at tasseling and flowering. Nevertheless, foliar application of $\mathrm{Zn}$ resulted in high $\mathrm{Zn}$ concentrations in corn grain and stover, and also higher $\mathrm{Zn}$ uptake in corn stover. Zee \& O'Brian (1970) reported that in wheat and barley a large portion of Zn comes through its remobilization from leaves. Xue et al. (2012) also observed that remobilization of $\mathrm{Zn}$ from leaves to grain contributed to the $\mathrm{Zn}$ content of grain. Thus foliarapplied $\mathrm{Zn}$ that then easily moves to corn grain should be adopted as a practice for agronomic biofortification of corn.

From the viewpoint of biofortification of corn grain, $\mathrm{Zn}$-coated urea was as good as foliar application. Further, Zn-coated urea applied to the soil resulted in significantly higher $\mathrm{Zn}$ uptake in corn grain and stover than foliar allocations. The $\mathrm{Zn}$-coated urea, supplying nearly half the $\mathrm{Zn}$ as compared to soil application of $\mathrm{Zn}$ sulphate, was significantly superior to the latter from the viewpoint of $\mathrm{Zn}$ biofortification of corn grain and stover. This could be due to concomitant availability of $\mathrm{Zn}$ and $\mathrm{N}$ to the crop roots. This is supported by the fact that $\mathrm{Zn}$ fertilization of corn increased the $\mathrm{N}$ concentration and uptake by corn grain and stover. A positive $\mathrm{N} x \mathrm{Zn}$ interaction has been reported in rice (Lakshmanan et al. 2005, Pooniya \& Shivay 2012) and wheat (Kutman et al. 2012, Wu et al. 2010). In these studies increased Zn 
uptake due to $\mathrm{N}$ fertilization has been reported. The present study shows that the reverse (increased $\mathrm{N}$ concentration due to $\mathrm{Zn}$ fertilization) also occurs.

The results of the present study shows that for agronomic $\mathrm{Zn}$ biofortification of corn grain and stover, foliar application of $1 \mathrm{~kg} \mathrm{Zn}$ sulphate ha ${ }^{-1}$ (in two sprays at tasseling and initiation of flowering) or application of $\mathrm{Zn}$-coated urea is better than soil application of $\mathrm{Zn}$ sulphate.

\section{Acknowledgements}

Our sincere thanks are due to Director, Joint Director Research and Head, Division of Agronomy, Indian Agricultural Research Institute, New Delhi for their advice and support. Rajendra Prasad is grateful to the Indian National Science Academy and Indian Agricultural Research Institute for granting him INSA Honorary Scientist and Adjunct Professor Positions, respectively.

\section{References}

Alloway BJ (2004) Zinc in soils and crop nutrition. International Zinc association (IZA), Brussel.

Broadley MR, White PJ, Hammond J, Zelko I, \& Lux A (2007) Zinc in plants. New Phytologist 173: 677-702

Cakmak I (2000) Role of zinc in protecting plant cells from reactive oxygen species. New Phytologist 146: 185205

Cakmak I (2002) Plant nutrition research: priorities to meet human needs for food in sustainable ways. Plant \& Soil 247: 3-24

Cakmak I (2008) Enrichment of cereal grains with zinc: agronomic or genetic biofortification? Plant \& Soil 302: $1-17$

Cakmak I, Kalayci M, Ekiz H, Braun HJ, Kilinc Y \& Yilmaz A (1999) Zinc deficiency as a practical problem in plant and human nutrition in Turkey: a NATO science for stability project. Field Crops Research 60: 175188

Cakmak I, Sari N, Marschner H, Ekiz H, Kalayci M, Yilmaz A \& Braun HJ (1996) Phytosiderophore release in bread and durum wheat genotypes differing in zinc efficiency. Plant \& Soil 180: 183-189

FAO (1996) Human vitamin and mineral requirements. No. 32. Report of a joint FAO/IAEA/WHO expert consultation. Corporate document repository, Rome.

Fertilizer Statistics (2011-12) The Fertilizer Association of India, FAI House, 10 Shaheed Jit Singh Marg, New Delhi.

Gibson RS (1994) Zinc nutrition in developing countries. Nutrition Research Review 7: 151-173

Gomez KA \& Gomez AA (1984) Statistical procedures for agricultural research. John Wiley \& Sons, New York.

Graham RD \& Welch RM (1996) Breeding for staple food crops with high micronutrient density: working papers on agricultural strategies for micronutrients No. 3. International Food policy Institute, Washington DC.

Hanway JJ \& Heidel H (1952) Soil analysis methods as used in Iowa State College Soil Testing Laboratory. Bulletin 57. Ames, IA: Iowa State College of Agriculture.

Khoshgoftarmanesh AH, Schulin R, Chaney RL, Daneshbakhsh B \& Afyuni M (2009) Micronutrient efficient genotypes for crop yield and nutritional quality in sustainable agriculture: a review. Agronomy for Sustainable Development 30: 83-107

Kutman UB, Yildiz B, Ozturk L \& Cakamk I (2012) Biofortification of durum wheat with zinc through soil and foliar application of nitrogen. Cereal Chemistry 87: 1-9

Lakshmanan R, Prasad R \& Jain MC (2005) Yield and uptake of micronutrients by rice as influenced by duration of variety and nitrogen utilization. Archives of Agronomy \& Soil Science 51: 1-14

Lindsay WL \& Norvell WA (1978) Development of DTPA soil test for zinc, iron, manganese and copper. Soil Science Society of America Journal 42: 421-428

Martens DC \& Lindsay WL (1990) Testing soils for copper, iron, manganese, and zinc. In: Westerman RL (ed) Soil testing and plant analysis. Soil Science Society of America, Madison, pp 229-273

Olsen R, Cole CV, Watanabe FS \& Dean LA (1954) Estimation of available phosphorus in soils by extraction with sodium bicarbonate. Circular 939 United States Department of Agriculture. Washington, DC: US Government Printing Office.

Paul AA, Bates CJ, Prentice A, Day KC \& Tsuchiya H (1998) Zinc and phytate intake of rural Gambian infants: contributions from breast milk and weaning foods. International Journal of Food Science \& Nutrition 49: $141-155$

Pfeiffer WH \& McClafferty B (2007) Biofortification: breeding micronutrient-dense crops. In: Kang MS, Priyadarshan PM (eds) Breeding major food staples for the 21st century. Blackwell Scientific, Oxford, pp $61-91$ 
Pooniya V \& Shivay YS (2013) Enrichment of Basmati rice grain and straw with zinc and nitrogen through fertifortification and summer green manuring under Indo-Gangetic plains of India. Journal of Plant Nutrition 36(1): 91-117

Prasad R, Shivay YS, Kumar D \& Sharma SN (2006) Learning by Doing Exercises in Soil Fertility (A Practical Manual for Soil Fertility). New Delhi: Division of Agronomy, Indian Agricultural Research Institute.

Ruel MT \& Bouis HE (1998) Plant breeding: a long term strategy for the control of zinc deficiency in vulnerable populations. American Journal of Clinical Nutrition 68: 488S-494S

Shivay YS \& Prasad R (2012) Zinc-coated urea improves productivity and quality of Basmati rice (Oryza sativa L.) under zinc stress condition. Journal of Plant Nutrition 35: 928-951

Shivay YS, Prasad R \& Rahal A (2010) Genotypic variation for productivity, zinc utilization efficiencies and kernel quality in aromatic rices under low available zinc conditions. Journal of Plant Nutrition 33: 18351848

Subbiah BV \& Asija GL (1956) A rapid procedure for the determination of available nitrogen in soils. Current Science 25: $259-260$

Walkley AJ \& Black IA (1934) An examination of the Degtjareff method for determination soil organic matter and a proposed modification of the chromic acid titration method. Soil Science 37: $29-38$

White PJ \& Broadley MR (2005) Biofortifying crops with essential mineral elements. Trends in Plant Science 10: $586-593$

WHO (2002) The world health report. World Health Organisation, Geneva, pp 72-104

Wu CY, Lu LL, Yang XE, Feng Y, Wei YY, Hao HL, Stoffella PJ \& He ZL (2010) Uptake, translocation and remobilization of zinc absorption at different growth stage by rice genotypes of different zinc densities. Journal of Agriculture \& Food Chemistry 58: 6767-6773

Xue YF, Yue SC, Zhang YQ, Cui ZL, Chen XP, Yang FC, Cakmak I, McGrath SP, Zhang FS \& Zou CQ (2012) Grain and shoot $\mathrm{Zn}$ accumulation in winter wheat as affected by nitrogen management. Plant \& Soil 261: 153-163

Zee SY \& O’Brian TP (1970) A special type of treachery element associated with xylem discontinuity in the floral axis of zinc. Australian Journal of Biological Sciences 23: 783-791

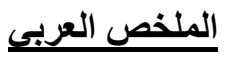

